\title{
Causes, clinical findings and therapeutic options in chylomicronemia syndrome, a special form of hypertriglyceridemia
}

\author{
György Paragh ${ }^{1 *}$, Ákos Németh ${ }^{1}$, Mariann Harangi ${ }^{1}$, Maciej Banach ${ }^{2,3}$ and Péter Fülöp ${ }^{1}$
}

\begin{abstract}
The prevalence of hypertriglyceridemia has been increasing worldwide. Attention is drawn to the fact that the frequency of a special hypertriglyceridemia entity, named chylomicronemia syndrome, is variable among its different forms. The monogenic form, termed familial chylomicronemia syndrome, is rare, occuring in 1 in every 1 million persons. On the other hand, the prevalence of the polygenic form of chylomicronemia syndrome is around 1:600. On the basis of the genetical alterations, other factors, such as obesity, alcohol consumption, uncontrolled diabetes mellitus and certain drugs may significantly contribute to the development of the multifactorial form. In this review, we aimed to highlight the recent findings about the clinical and laboratory features, differential diagnosis, as well as the epidemiology of the monogenic and polygenic forms of chylomicronemias. Regarding the therapy, differentiation between the two types of the chylomicronemia syndrome is essential, as well. Thus, proper treatment options of chylomicronemia and hypertriglyceridemia will be also summarized, emphasizing the newest therapeutic approaches, as novel agents may offer solution for the effective treatment of these conditions.
\end{abstract}

Keywords: Chylomicronemia syndrome, Lipoprotein lipase, apoC3 inhibitor, MTP inhibitor, Angiopoietin-like protein-3

\section{Introduction}

Showing high inter-individual variations, hypertriglyceridemia may affect about one third of the population [1]. Ranging from mild and moderate to severe forms, hypertriglyceridemia increases cardiovascular risk and predisposes to acute pancreatitis. Triglycerides are transported in the circulation in chylomicrons that carry dietary (exogenous) fat and very-low density lipoproteins (VLDL) that contain liver-related (endogenous) lipids. Regardless of their origin, triglycerides are hydrolyzed by the endothelium-bound lipoprotein lipase (LPL), which is a key component of the clearance of the triglyceride-

\footnotetext{
* Correspondence: paragh@belklinika.com

'Division of Metabolic Diseases, Department of Internal Medicine, University of Debrecen Faculty of Medicine, Nagyerdei krt. 98, Debrecen $\mathrm{H}-4032$, Hungary

Full list of author information is available at the end of the article
}

rich lipoproteins [2]. A significant portion of the patients experience significantly elevated chylomicron concentrations, thus increased serum triglyceride levels concomitant with elevated serum cholesterol levels.

Chylomicronemia syndrome (CS) may be due to very rare monogenic mutations in the genes encoding the LPL enzyme or its regulators leading to familial chylomicronemia syndrome (FCS) and with the phenotypical appearance of Fredrickson type 1 hyperlipoproteinemia. More commonly, chylomicronemia is a result of clustering multiple genetic variants coexisting with one or more secondary hypertriglyceridemia-aggravating factors leading to multifactorial chylomicronemia syndrome (MFCS, Frecrickson type 5 hyperlipoproteinemia). A third and uncommon form of chylomicronemia syndrome is familial partial lipodystrophy (FPLD) [2]. It is important to mention, that CS may also develop on the 
basis of autoimmunity (autoimmune hyperlipidemia) and in patients with glucose-6-phosphate deficiency [2].

Additionally, hypertriglyceridemia may also be due to another polygenic origin, apperaring as Fredrickson type 4 hyperlipoproteinemia, which is characterized by excess production of VLDL from the liver and may coexist with other co-morbidities. Familial dysbetalipoproteinemia, characterized by homozygous apolipoprotein (apo) E2 mutations, is also associated with significant elevations in triglyceride and cholesterol levels in the serum. In turn, secondary forms of hypertriglyceridaemia are far more common, in which, increased triglyceride concentration is caused by poorly controlled type 2 diabetes mellitus, hypothyroidism, nephrotic syndrome or administration of certain drugs (Fig. 1) [3]. Therefore, finding the exact cause behind hypertriglyceridemia may be a significant challenge to the clinician. In this paper, we focused on chylomicronemia especially from the clinical point of view and discussed the newest etiologic considerations including genetic background. We also detailed the recent therapeutic options, their potential benefits and highlighted the newest developments.

\section{Lipid metabolism}

The amount of circulating fats depends on the balance between the endogenous and exogenous lipid metabolism. Exogenous lipid metabolism refers to the breakdown of dietary lipids, followed by the absorption in the small intestine and conversion to chylomicrons. Entering the endogenous metabolism, chylomicron loses a significant portion of its triglyceride content due to the activity of LPL anchored to the vessel wall, with the triglycerides hydrolyzed into fatty acids and monoglycerides [4]. Chylomicron remnant, which is poorer in triglycerides, is taken up by the remnant receptors of the hepatocytes and may thus enter endogenous lipid metabolism. Triglyceride and other lipid components are attached to the apolipoprotein (apo)B100 by the microsomal triglyceride transfer protein (MTP), forming VLDL. Once in the circulation, VLDL is also degraded by the LPL yielding intermediate density lipoprotein (IDL), that may further be converted to low-density lipoprotein (LDL) by the hepatic lipase [5].

\section{Factors influencing lipoprotein lipase activity}

Influenced by a number of cofactors, LPL plays a key role in both the exogenous and the endogenous lipid metabolism. ApoC2 serves as an activator of the enzyme [6-8], hence lack of apoC2 leads to a curbed LPL function. Lipase maturation factor-1 (LMF1) plays a role in the formation of the proper structure of LPL and regulates its expression [9]. As LPL is mainly synthetized in white adipose tissue and skeletal and cardiac muscle, glycosylphosphatidylinositolanchored high density lipoprotein-binding protein 1 (GPIHBP1) plays a crucial role in its proper function, mediating the transport of LPL into the capillary endothelial

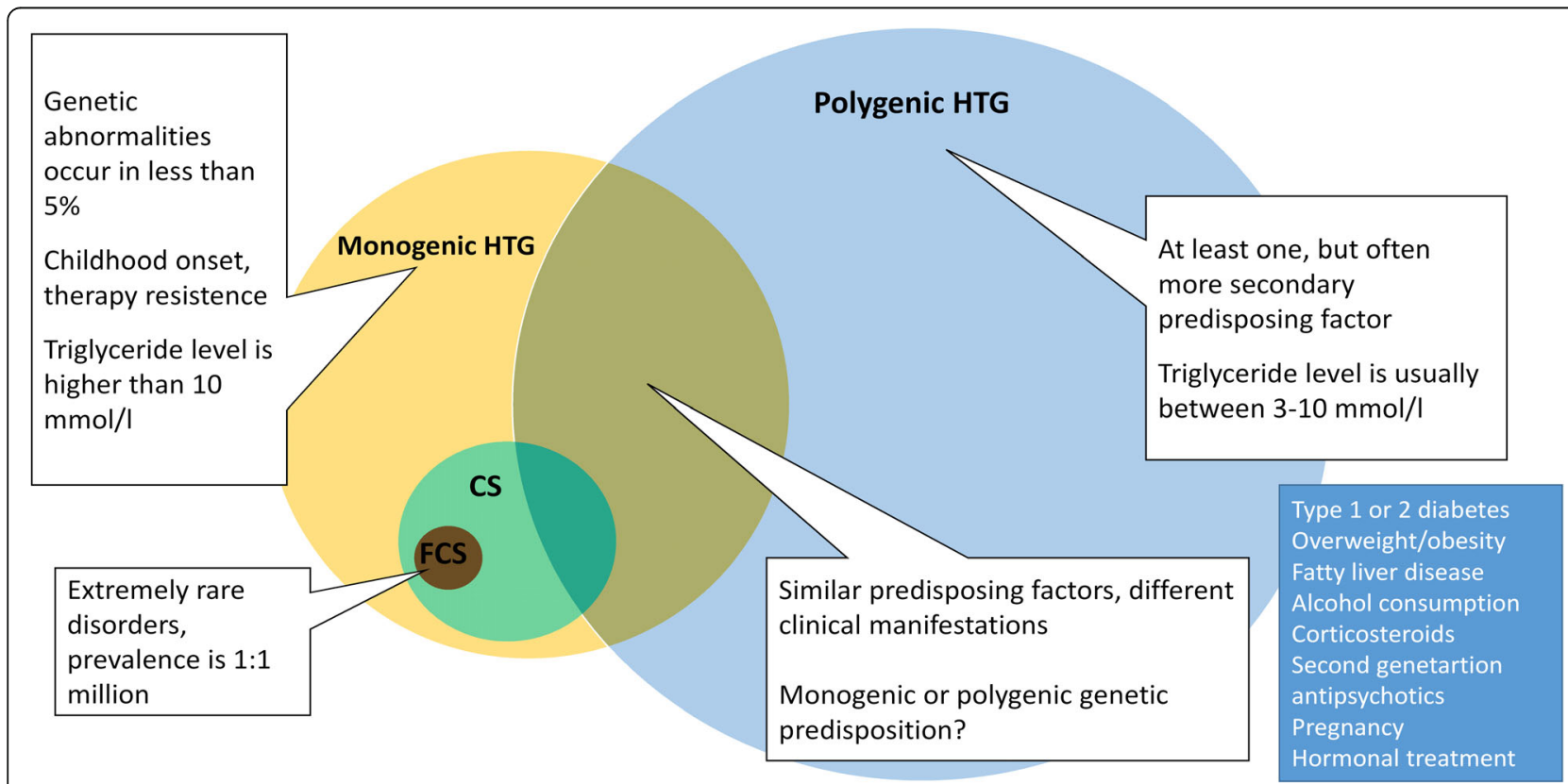

Fig. 1 Differential diagnosis of hypertriglyceridemias. Differential diagnosis of elevated triglyceride levels and separation of monogenic and polygenic forms can be challenging in the everyday clinical practice. Secondary forms should be excluded, then characteristics of the monogenic form have to be assessed including childhood onset, resistance to therapy, and severe hypertriglyceridemia exceeding $10 \mathrm{mmol} / \mathrm{l}$. Only a small portion of patients with hypertriglyceridemia present chylomicronemia, and, from these, FCS is a rarity. It should also be noted, that genetic and environmental factors may modify the phenotype and the clinical features of any form 
cells and anchoring it on their surface [10]. ApoA5 stabilizes the LPL-apoC2 complex by promoting endothelial surface binding of triglyceride-rich lipoproteins to heparan sulfate proteoglycan (HSPG) $[11,12]$. ApoE regulates the clearance of the triglyceride-rich lipoproteins, while apoC3 [13] and angiopoietin-like proteins (ANGPTL) 3, 4 and 8 [14-23] inhibit the activity of LPL. The combined effect of these factors sets the actual LPL activity, which determines the extent of triglyceride degradation and thus has a significant impact on the development of hypertriglyceridemia (Fig. 2) [24].

\section{Clinical features of hypertriglyceridemia}

Previous studies have shown that familial chylomicronemia syndrome, in most cases, is a result of a genetic- related alterations in LPL function [25-28]. Loss-offunction mutations lead to a significant reduction in the degradation of triglyceride-rich molecules as chylomicron and VLDL, resulting in severe hypertriglyceridemia. The serum in these patients often appears to be opalescent or even milky, while accumulation of the triglycerides in the skin elicits a local inflammatory response $[29,30]$. This presents as a yellowish prominent papule filled with lipid-containing macrophages and surrounded by a red yard, called eruptive xanthoma [31]. The fatty acid pattern of chylomicron (CM) and diabetic eruptive xanthoma triglycerides are similar based on a correlative biochemical, histochemical and electron microscopic study supporting the theory of the plasma lipoprotein origin of xanthoma lipids [32].

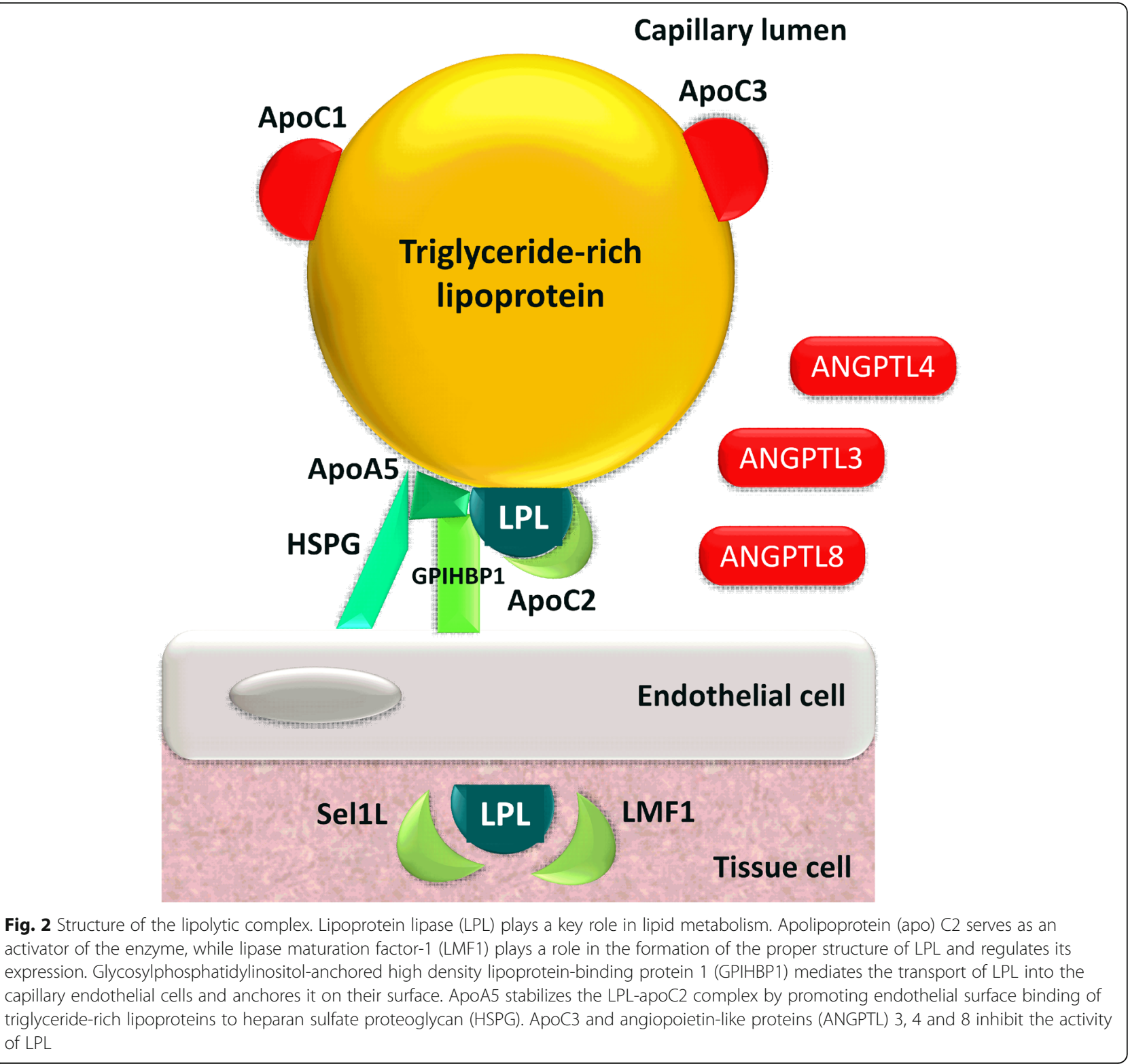


Ophthalmological examination may reveal lipemia retinalis, which is the appearance of white, discolored fundus veins and salmon pink areas. This condition, however, is not associated with visual impairment [29, 30]. On the other hand, infiltrating macrophages and Kupffer cells take up large amounts of chylomicrons in the liver, leading to hepatomegaly. A similar phenomenon can also be observed in the spleen, as well. It is important to emphasize, that these lesions are reversible and proper treatment of hypertriglyceridemia leads to their disappearance [29].

The most serious clinical complication in hypertriglyceridemia and FCS is the development of acute pancreatitis with a potential mortality of 5-6\% [33-37]. Previous studies indicated that $15 \%$ of the patients with severe hypertriglyceridemia had a history of acute pancreatitis [38] with a 5-year pancreatitis rate being greater than $3.5 \%$ [39]. The absolute and relative risks of developing acute pancreatitis increase slightly above triglyceride levels of $10 \mathrm{mmol} / \mathrm{l}[3,40,41]$, and then even more when serum triglycerides exceed $20 \mathrm{mmol} / \mathrm{l}$ [38]. This is due to the fact that pancreatic lipase enters the capillaries of the pancreas during the state of hypertriglyceridemia. As a result, partial lipoprotein lipolysis is initiated and the release of free fatty acids damages directly the cells and activates trypsinogen leading to local inflammation and pancreatic cell necrosis [3, 34, 41]. The risk of pancreatitis can significantly be reduced by lowering triglyceride levels, suggesting that significant triglyceride accumulation is a potential life-threatening condition impairing quality of life. Mutations in the genes regulating LPL activity may modify the hydrolysis of the chylomicron particles and usually result in less severe phenotypes than that of the mutations in the $L P L$ and apoC2 genes [27, 42].

\section{Epidemiology of chylomicronemia syndrome}

Based on the circulating triglyceride levels, hypertriglyceridemia can generally be divided into two categories: (i) a mild to moderate form in which fasting triglyceride levels are between 2 and $10 \mathrm{mmol} / \mathrm{l}$ and (ii) a severe form in which triglyceride levels are above $10 \mathrm{mmol} / \mathrm{l}$ [43]. Regardless of the clinical consequences, chylomicronemia is described as an abnormal accumulation of chylomicrons in the plasma for $12-14 \mathrm{~h}$ after a meal. Of note, in individuals with undisturbed lipid metabolism, chylomicrons disappear from the serum $2-3 \mathrm{~h}$ after a meal $[3,26-28,44]$. If chylomicrons are present in the serum in the fasting state, triglyceride levels exceeding $10 \mathrm{mmol} / \mathrm{l}$ may be detected. A typical finding in CS is highly lipemic fasting blood showing a creamy white layer on its surface. After an overnight storage of the blood sample or after centrifugation, this white chylomicron layer can be detected above the other components of the plasma. In CS, at least one of the following clinical findings or symptoms is present: eruptive xanthoma of the trunk and limbs, lipemia retinalis, recurrent abdominal pain, acute or recurrent pancreatitis, and hepatosplenomegaly (Fig. 3) [26, 27, 45, 46].

About 95\% of chylomicronemia is of multifactorial origin (MFCS), while 5\% has monogenic background with autosomal recessive inheritance (FCS) with rare cases of FPLD. The polygenic/multifactorial form is estimated to occur in 1 in every 600 individuals, while the prevalence of monogenic chylomicronemia is $1: 1,000,000$ [47]. The latter prevalence is similar to that of the homozygous form of familial hypercholesterolemia. More than $90 \%$ of monogenic chylomicronemia is due to mutations in the $L P L$ gene [25]. Indeed, more than 114 LPL gene mutations have been described so far [25, 26, 48-55]. Other mutations influencing LPL activity are much less common, such as mutations in the genes of the regulators of LPL including apoC2, apoA5, LMF-1, and GPIHBP1 [28, 42].

Assessment of the genetic background of MFCS has been slightly altered in the last few years $[56,57]$. According to the recent data, FCS is bi-allelic, due to homozygous or compound heterozygous mutations in the genes of LPL, ApoC2, GPIHBP1, LMF1 that cardinally affect the catabolic efficacy of LPL complex. However, causal involvement of mutations of ApoA5 in FCS is ambiguous, since ApoA5 may not be an essential cofactor for LDL activity. Therefore, its deficiency may not be sufficient to abolish LPL activity [58]. Furthermore, in patients diagnosed with MFCS, causes include monoallelic pathogenic variants in one of the above 5 genes associated with high polygenic risk [48]. Indeed, a recent study found that some patients diagnosed with FCS exhibiting LPL activity deficiency harbored mutations only in heterozygosity, which raises the question of the involvement of concomitant SNPs, new genes or environmental factors in the manifestation of FCS [59]. It must be underlined that CS cases with monogenic origin are rare, and polygenic risk is the most common and important susceptibility factor for CS [56].

On the basis of complex genetic susceptibility affecting heterozygous variants of the above mentioned genes and/or common polymorphisms of other genes with smaller impact on LPL function, multifactorial chylomicronemia syndrome is usually provoked by secondary factors including obesity, alcohol consumption, poorly controlled diabetes mellitus, hypothyroidism, nephrotic syndrome and many commonly used medications as estrogen, estrogen receptor antagonists, corticosteroids, thiazide diuretics, beta-blockers, retinoids, resins, antipsychotics, antidepressants and antiretroviral agents [3]. In this form, concentrations of a wide range of lipoprotein fractions are elevated, such as apoB48-containing 


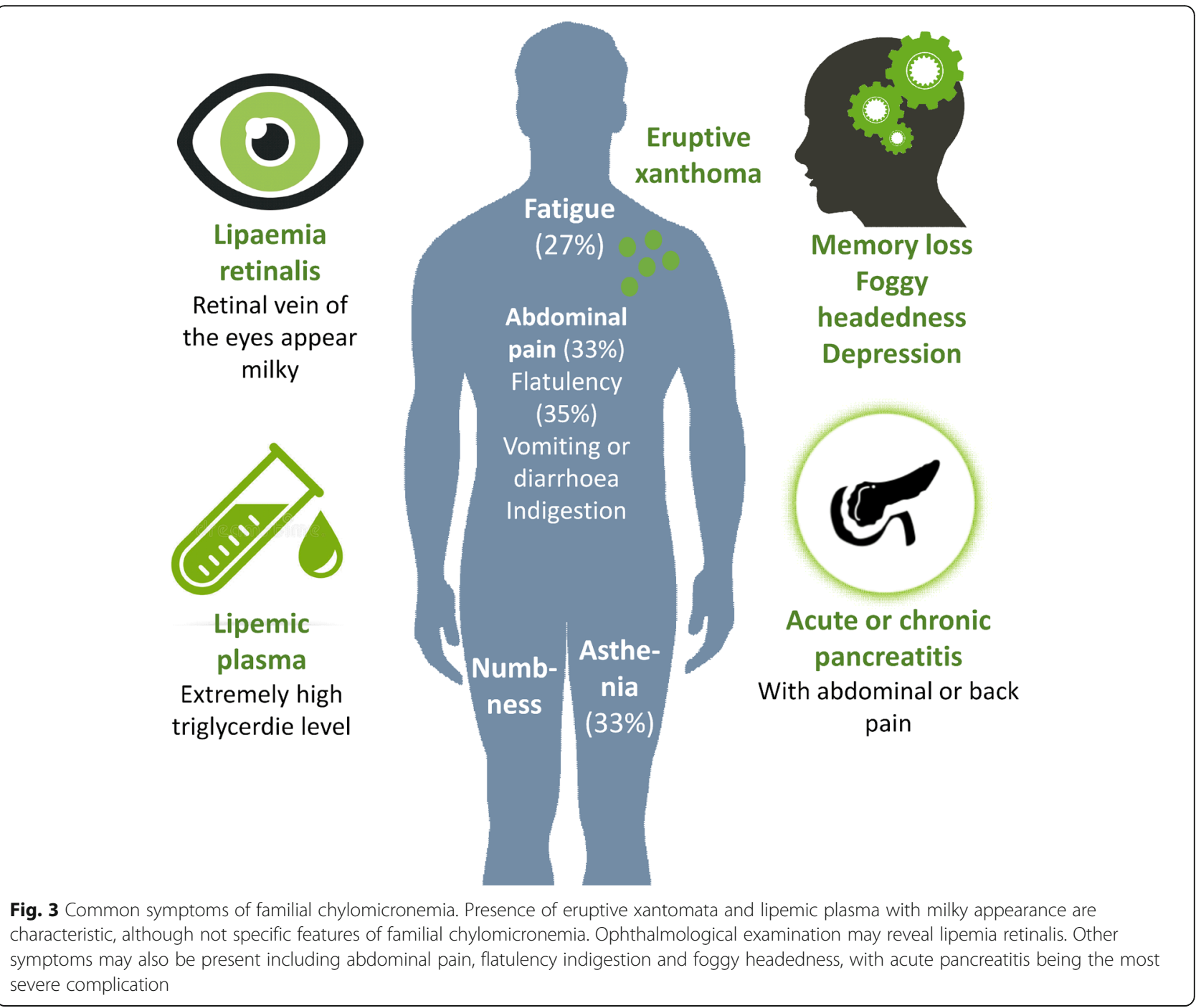

chylomicron remnants, apoB100-containing VLDL, VLDL remnants and IDL, together with decreased highdensity lipoprotein (HDL) levels [60]. Postprandial accumulation of both apoB48-containing and hepatic apoB100-containing triglyceride-rich lipoprotein remnants is considered to be pro-atherogenic. It is important to emphasize that multifactorial chylomicronemia, as a marker of postprandial lipemia, is also considered to be a pro-atherogenic metabolic condition [60].

In about $30 \%$ of patients with CS, neither recessive nor heterozygous variants, or frequent single nucleotide polymorphisms (SNP) can be detected. These are called unidentified chylomicronaemias. Regardless of the origin, the risk of life-threatening pancreatitis is increased. Cardiovascular risk may not be significantly affected in the monogenic form, while it is increased in patients carrying multifactorial CS [25]. A recent multicenter study evaluated the risk of cardiovascular complications retrospectively, based on a 10-year comparative follow- up of FCS versus MFCS patients. Twenty-nine FCS and 124 MFCS patients, with genetic diagnosis, in 4 lipid clinics were matched with 413 controls were enrolled. The ischemic risk (risk of hospitalization for ischemic cardiovascular disease) was lower in FCS than in MFCS ( $\mathrm{HR}=3 p<0.05)$. It must be noted that they could not detect any major adverse cardiovascular events (acute myocardial infarction, cerebral ischemia, stroke, not specified as hemorrhage or infarction, transient cerebral ischemic attacks, and related syndromes) during the 10-year followup, underlining the minor risk of cardiovascular complications in FCS [61]. Monogenic chylomicronemia typically occurs in neonates and young children or in the adolescence, at the latest $[26,44]$. Besides the above mentioned, hypertriglyceridemia with genetic origin may either have autosomal dominant or polygenic inheritance involving inactivating $L P L$ gene mutations or variants modifying apoB metabolism and the diseases may also be associated with chylomicronemia syndrome [62]. 
The third, uncommon form of CS is FPLD, which is a heterogenous group of rare conditions characterized by adipose tissue maldevelopment and lipoatrophy. The condition is characterized by limited capacity of adipose tissue to store fat leading to subsequent metabolic abnormalities, such as insulin resistance, liver steatosis and severe hypertriglyceridemia [2, 63, 64]. Of the several forms of FPLD, the two most common are the Dunnigan (type 2) and Köbberling (type 1) varieties. Mutations of the LMNA and the PPARG genes are usually found in patients with the Dunnigan form, while no mutations in single genes have been identified in the Köbberling phenotype, although polygenic background has been confirmed [65]. It is important to emphasize that the latter form shares many features with metabolic syndrome; however, careful physical examination of the fat distribution may help a lot. Familial dysbetalipoproteinemia (Fredrickson type 3 hyperlipoproteinaemia) can be another possible cause of chylomicronemia if it co-exists with a secondary form of hypertriglyceridemia such as pregnancy or administration of oral contraceptives [66].

Other conditions, such as lupus erythematosus, Sjögren's syndrome or multiple myeloma may also lead to chylomicronemia and hypertriglyceridemia [2]. Antibodies to LPL, VLDL or GPIHBP1 are reported to develop in these patients, resulting in autoimmune hyperlipidemia [67].

Identification and proper control of conditions provoking or unmasking multifactorial chylomicronemia are of major importance, as these factors are the most common causes of hypertriglyceridemia in the everyday practice [46].

\section{Diagnosis of chylomicronemia syndrome}

In general, distinction between the two forms may be made on the basis of clinical symptoms, laboratory results, and genetic tests; however, the proper diagnosis may be hard to establish due to the various factors that influence circulating triglyceride concentration.

\section{Monogenic form (FCS)}

Symptoms begin in early childhood and the clinical abnormalities mentioned earlier as abdominal pain of unknown origin, eruptive xanthomas, hepatosplenomegaly, and recurrent pancreatitis are common $[26,27,45,46]$. Previous studies have shown that a $1.1 \mathrm{mmol} / \mathrm{l}$ elevation in the serum triglyceride level increases the risk of acute pancreatitis by $4 \%[3,68]$. This association has also been observed in prospective studies in moderate hypertriglyceridemia [69]. In this form, neurological symptoms as irritability, memory impairment, dementia, and depression are often observed [70]. Abdominal complaints result in decreased food intake, deteriorating quality of life, and decreased daily activity [71, 72]. Plasma triglyceride is usually higher than $10 \mathrm{mmol} / \mathrm{l}$ and the triglyceride:cholesterol ratio is above 2.2 , with apoB100 levels exceeding $100 \mathrm{mg} / \mathrm{dl}$. Lipoprotein lipase activity decreases drastically $10 \mathrm{~min}$ after intravenous administration of heparin.

\section{Polygenic chylomicronemia (MFCS)}

In addition to the high triglyceride levels, presence of other triggering factors may be detected in this form, as detailed above. Moderate hypertriglyceridemia and a loss-of-function mutation in apoA5 are commonly observed [73]. A previous genome wide association study (GWAS) proved that several single nucleotide polymorphisms (SNPs) associated with hypertriglyceridemia in normolipidemic samples, including SNPs in the genes of APOA5, TRIB1, TBL2, GCKR, GALNT2 and ANGP TL3, were significantly associated with hyperlipoproteinemia Fredrickson types 2B, 3, 4 and 5 [56]. The findings of the GWAS studies reinforce that the genetic contribution to most of the hyperlipoproteinemia phenotypes is complex, but also suggest that additional genes or non-genetic factors may still play an important role. It is not surprising that Pplasma triglyceride levels are much more variable and more sensitive to diet and fibrate therapy compared to monogenic forms.

\section{FCS screening}

The score system recommended by Moulin et al. seems to be promising in screening for FCS [74] (Table 1). Based on the information to date, recent knowledge regarding the separation of monogenic and polygenic chylomicronemias is summarized in Table 2.

Table 1 Scoring of familial chylomicronemia syndrome, according to Moulin et al.

\begin{tabular}{lc}
\hline & Score \\
\hline 1. Fasting TGs $>10 \mathrm{mmol} / \mathrm{L}$ for 3 consecutive blood analysis & +5 \\
Fasting TGS $>20 \mathrm{mmol} / \mathrm{L}$ at least once & +1 \\
2. Previous TGs $<2 \mathrm{mmol} / \mathrm{L}$ & -5 \\
3. No secondary factor (except pregnancy and ethinylestradiol) & +2 \\
4. History of pancreatitis & +1 \\
5. Unexplanied recurrent abdominal pain & +1 \\
6. No history of familial combined hyperlipidaemia & +1 \\
7. No response (TG decrease $<20 \%)$ to hypolipidaemic & +1 \\
treatment & \\
8. Onset of symtoms at age: & +1 \\
$-<40$ years & +2 \\
$-<20$ years & +3 \\
\hline
\end{tabular}

$>10$ : FCS very likely

$<9$ FCS unlikely

$<8$ FCS very unlikely 
Table 2 Characteristics of different types of primary chylomicronemia syndrome

\begin{tabular}{|c|c|c|}
\hline & Polygenic (multifactorial chylomicronemia - MCS) & $\begin{array}{l}\text { Monogenic (familial chylomicronemia - } \\
\text { FCS) }\end{array}$ \\
\hline Frequency & $95 \%$ & $5 \%$ \\
\hline Clinical findings & $\begin{array}{l}\text { Chylomicronemia, eruptive xanthoma, lipemia retinalis, } \\
\text { abdominal pain, recidiv pancreatitis, hepatosplenomegaly }\end{array}$ & $\begin{array}{l}\text { Chylomicronemia, eruptive xanthoma, lipemia } \\
\text { retinalis, abdominal pain, recidiv pancreatitis, } \\
\text { hepatosplenomegaly }\end{array}$ \\
\hline Onset of the symtoms & In adult & Early age, childhood and adolescent \\
\hline $\begin{array}{l}\text { Secondary factors which initiate the } \\
\text { symptoms }\end{array}$ & $\begin{array}{l}\text { High amount fatty food intake, alcohol, diabetes mellitus, } \\
\text { obesity, hypothyreosis, metabolic syndrome, nephrotic } \\
\text { syndrome, drugs (oestrogen, corticosteroid, retinoid, beta- } \\
\text { blockers, thiazide, resin, second generation antipsychotic and } \\
\text { antiretroviral agents) }\end{array}$ & - \\
\hline $\begin{array}{l}\text { Plasma left overnight is milky with a } \\
\text { creamy layer on top }\end{array}$ & + & +++ \\
\hline Triglyceride level & $<10 \mathrm{mmol} / \mathrm{l}$, or less & $>10 \mathrm{mmol} / \mathrm{l}$ \\
\hline Plasma apoB< 100 mg/dl & & + \\
\hline $\begin{array}{l}\text { Triglyceride/Cholesterol ratio > } 2.2 \\
\mathrm{mmol} / \mathrm{l}(5 \mathrm{mg} / \mathrm{mg})\end{array}$ & + & +++ \\
\hline $\begin{array}{l}\text { I.v. } 50 \mathrm{U} / \mathrm{kg} \text { heparin induced } \\
\text { lipoprotein lipase activity }\end{array}$ & $\begin{array}{l}\text { After } 10 \text { min normal, } \\
\text { After } 60 \text { min reduced }\end{array}$ & very low \\
\hline $\begin{array}{l}\text { Effect of tradicional lipid lowering } \\
\text { therapy (fibrate, acidum nicotinicum, } \\
\text { omega-3 fatty acid) }\end{array}$ & Moderate effect & no effect \\
\hline $\begin{array}{l}\text { Secondary risk factor treatment } \\
\text { improve the symptoms }\end{array}$ & ++++ & \\
\hline Genetic background & $\begin{array}{l}\text { Single copy or monoallelic (i.e. heterozygous) rare variants in } \\
\text { LPL, APOC2, APOA5, LMF1 and GPIHBP1 gene and polygenic } \\
\text { risk from common variants associated with TG levels }\end{array}$ & $\begin{array}{l}\text { Frequently: LPL, ApoC2 mutations } \\
\text { Rare cases: ApoA5, GPIHBP1, LMF1 }\end{array}$ \\
\hline
\end{tabular}

\section{Treatment of chylomicronemia}

The key components of CS management are focusing primarily on pancreatitis prevention and secondarily on cardiovascular risk lowering including prevention of nonalcoholic steatohepatitis (NASH) and type 2 diabetes mellitus.

\section{Lifestyle and diet}

Non-pharmacologic interventions including cessation of aggravating factors and introducing very-low fat diet that contain less fat than $15 \%$ of the total calories is recommended, which may significantly reduce clinical signs and symptoms. In FCS patients dietary fat restriction to less than 5 to $10 \%$ of calories consumed and medium chain triglyceride may help to decrease chylomicron formation [2]. At the same time, diet helps to normalize body weight, however, sustaining such diet on a longterm basis is a huge challenge, especially in young individuals. Overweight and diabetic patients benefit from weight reduction together with high-fiber and lowcarbohydrate diet. Discontinuation of alcohol helps to lower VLDL production and reduces pancreatitis incidence, while removal of potential triggering drugs and treatment of those conditions that are associated with hypertriglyceridemia are of major importance, as well $[26,44]$.

\section{Drugs}

Lifestyle treatment alone is usually not enough, thus it should be supplemented with medication. Of the currently available drug treatments, the most commonly used are fibrates, nicotinic acid and its derivatives, and statins. Their lipid lowering efficacy in FCS, however, unfortunately lags behind that desired [75, 76].

\section{Fibrates}

Via the peroxisome proliferator activating receptor (PPAR)- $\alpha$, fibrates inhibit apoC3 expression and hepatic synthesis of the triglyceride-rich VLDL particles; however, they do not have an impact on the level of the intestinum-derived chylomicrons. Fibrates also enhance LPL-mediated lipolysis by reducing apoC3 levels, which is an inhibitor of LPL activity [3]. Fibrates possess a triglyceride lowering effect of up to $50 \%$ [3, 77-79]. In individuals with mixed dyslipidemia that is associated with the release of chylomicrons and VLDL particles, fibrates reduce triglyceride levels by decreasing the number of VLDL particles. In FCS, characterized by loss-of- 
function LPL gene mutation, the response to treatment is very modest due to the lack of the enzyme activity.

A previous study demonstrated the efficacy and safety of pemafibrate, a novel selective peroxisome proliferator-activated receptor $\alpha$ modulator (SPPARM $\alpha$ ) in three patients with severe hypertriglyceridemia [80]. However, a recent case report verified a modest efficacy of pemafibrate in a woman with LPL deficiency [81]. Further studies are needed to clarify the potential therapeutic role of pemafibrate in FCS.

\section{Niacin}

Niacin decreases lipolysis and free fatty acid release from adipose tissue by inhibiting hormone-sensitive triglyceride lipase [82]. It also inhibits diacylglycerol Oacyltransferase $2[3,77,79,83]$, which also contributes to curbed VLDL production. Indeed, the triglyceride lowering effect of niacin is between 5 and 35\% [84]. Additionally, niacin reduces the degradation of apoA1containing proteins and increases the expression of PPAR- gamma [85]; however, the common side effects seriously limit its use.

\section{$\omega-3$ fatty acids}

Intake of high doses of $\omega-3$ fatty acids (4-6g eicosapentaenoic acid (EPA) or doxosahexaenoic acid (DHA) daily) inhibits VLDL production, reduces the chylomicron size [86], enhances systemic lipolysis and promotes chylomicron plasma clearance by inhibiting apoC3 [87-90]. It also reduces apoC3 production [91] and increases chylomicron remnant clearance [86]. It can exert a triglyceride-lowering effect of up to $21 \%$ [92]. Recent data also indicate that icosapent ethyl (IPA), a purified derivative of EPA, is also effective in lowering triglyceride levels, and, even more importantly, reduces cardiovascular risk [93].

\section{Diacylglycerol 0-acyltransferase 1 (DGAT1) inhibitors}

Localized in the endoplasmic reticulum, DGAT1 is a key enzyme in triglyceride synthesis showing high expression in the intestine, liver and white adipose tissue [94, 95]. Unfortunately, previous studies indicated that, the use of the DGAT1 inhibitor AZD7687 had provoked severe nausea, vomiting, and intolerable diarrhea [96-98], therefore DGAT1 inhibitor development has been halted.

\section{ApoC3 inhibition}

ApoC3 is produced by the liver and small intestine and is found mainly in triglyceride-rich lipoproteins, such as chylomicrons and VLDL. Physiologically, apoC3 inhibits LPL and hepatic lipase activities as well as the hepatic uptake of triglyceride-rich lipoproteins [99]. Inhibition of apoC3 expression significantly increases LPL activity and decreases triglyceride production [100]. Mutations associated with decreased apoC3 have been found to reduce the risk of major cardiovascular events in addition to decreasing plasma triglyceride levels [101]. The apoC3 antisense oligonucleotide inhibits its protein production and was found to lower apoC3 levels by $77 \%$ and triglyceride levels by $43 \%$ in healthy subjects. This effect persisted for 4 weeks after discontinuation of the drug and no serious side effects were observed [102]. Another study showed an $80 \%$ apoC3 and $70 \%$ triglyceridelowering effect in monogenic chylomicronemia with LPL deficiency [103]. In phase 2 studies, the secondgeneration apoC3 inhibitor volanesorsen had a $31-71 \%$ triglyceride-lowering effect [104].

In the phase 3, randomized, double-blind, placebocontrolled APPROACH study, patients with familial chylomicronaemia syndrome received $300 \mathrm{mg}$ volanesorsen administered subcutaneously once a week. The apoC3 inhibitor showed a very potent and sustained effect, decreasing serum triglyceride levels by $77 \%$. No recurrent pancreatitis occurred, abdominal pain was reduced, and no side effects related to liver or kidney function were observed. The most common side effect was a local reaction at the injection site and, in 5 cases, a decrease in platelet count, which necessitated discontinuation of treatment [105]. The beneficial effects of volanesorsen were confirmed in MFCS patients by the COMPASS study as well, in which a $72 \%$ reduction in the triglyceride levels was observed in the patients treated with the apoC3 inhibitor. There was a significant reduction in the incidence of pancreatitis and the most common side effect was a local skin reaction. However, no significant difference in platelet count was observed. The study demonstrated that the apoC3 inhibitor treatment may have a significant triglyceride-lowering effect in hypertriglyceridaemia with or without familial chylomicronemia syndrome [106]. Based upon these results, the use of volanesorsen was approved in the European Union for the treatment of FCS in adults [107].

\section{LPL gene replacement therapy}

Alipogene tiparvovec is a kind of adenovirus-associated virus that encodes an increased activity variant of the human LPL gene [108-111] and can lower triglyceride levels by $40 \%$. However, due to its transient effect, the drug development was discontinued in 2017.

\section{Angiopoietin-like protein 3 (ANGPTL3) inhibition}

ANGPTL3 is mainly produced by the liver after meals reversibly inhibiting LPL activity [14]. Several studies have demonstrated that recombinant ANGPTL3 inhibits LPL activity in vitro [15-19]. ANGPTL3 is much more effective in the presence of ANGPTL8 and previous studies have shown that the effect of increased ANGP 
TL3 production on plasma triglyceride levels was significantly reduced in the absence of ANGPTL8 [21, 22, 112]. ANGPTL3 production in the liver is mediated by the oxidized sterol-activated liver X receptor (LXR) [113, 114] and LXR agonists increase circulating triglyceride levels [115]. Expression of ANGPTL3 is inhibited by PPAR- $\gamma$ agonists, statins, insulin, leptin, thyroid hormone, and lipopolysaccharides [116-121]. Patients with mutations in the ANGPTL3 gene had decreased total cholesterol, LDL, triglyceride levels, and HDL levels [23]. ANGPTL3 gene mutated mice express decreased triglyceride, total cholesterol and unesterified fatty acid concentrations in plasma, which can be reversed following administration of ANGPTL3-expressing adenovirus [122]. Also, ANGTPL3 antisense oligonucleotide reduces serum cholesterol and triglyceride levels [123] and a monoclonal antibody to ANGPTL3 named evinacumab was also effective in reducing triglyceride and cholesterol levels, as well as HDL and LDL-C and VLDL-C levels in mice $[124,125]$. The decrease might be due to increased degradation of LPL-mediated triglyceride-rich lipoproteins $[16,100,126]$. Additionally, vupanorsen, a second generation ANGTPL3 antisense oligonucleotide showed similar effects on apoC3 and triglyceride levels to that of volanesorsen, but was found to provoke less number of adverse effects [127].

\section{Statins}

Inhibiting the hepatic hydroxymethylglutaryl-coenzyme A (HMGCoA) reductase, statins promote the uptake of LDL particles from the circulation. However, no significant impact on LDL concentration was observed in primary CS [101]. Statins also increase the catabolism of the remnants of LDL and chylomicrons, contributing to the reduction of triglyceride levels [128]. Although these drugs cannot reduce chylomicrons or improve severely increased triglyceride levels, based upon the etiology of MFCS, statin therapy is a key player in cardiovascular disease risk reduction.

\section{MTP inhibitor}

MTP binds triglyceride and other lipid components to apoB100 and apoB48 [94, 129-132], therefore inhibiting this process may lead to reduced VLDL and chylomicron formation. The MTP inhibitor lomitapide is currently not approved in FCS, although provides a $30-40 \%$ triglyceride lowering effect in homozygous familial hypercholesterolemia [94, 129-131]. Gastrointestinal side effects, however, are common, including nausea, vomiting and diarrhea. The incidence of these side effects may significantly be reduced with increasing the dose gradually $[129,133,134]$. It also has to be mentioned that the use of MTP inhibitors increases liver fat content and the risk of developing steatohepatitis and fibrosis. Recurrence of pancreatitis could also be mitigated, due to the $60-70 \%$ reduction in triglyceride concentration with lomitapide therapy in monogenic chylomicronemia [130].

\section{Other preparations}

CAT-2003 is a novel conjugate of EPA and niacin that is hydrolyzed by fatty acid amine hydrolase to release EPA in cells. CAT-2003 blocks the maturation of sterol regulatory element-binding proteins (SREBP)- 1 and -2 , inhibiting the production of the proprotein convertase subtilisin/kexin type 9 (PCSK9), which leads to an increased number of LDL receptors on the cellular surface and decreased serum cholesterol and triglyceride levels [135]. Zimmer et al. have found that CAT-2003 reduced prandial triglyceride levels by $30 \%$ and postprandial concentrations by $90 \%$ [136]. In patients with familial hyperlipoproteinemia type 1 , the efficacy and safety of CAT2003 are recently studied including its effects on fasting levels of total and chylomicron triglycerides and postprandial total and chylomicron triglyceride clearance, as well as plasma non-HDL lipoprotein levels, and the frequency of adverse events. This study may also confirm the role of CAT-2003 in the treatment of hypertriglyceridemia $[135,137]$.

\section{Plasmapheresis}

In severe chylomicronemia and acute pancreatitis, plasmapheresis may be used to rapidly reduce the serum concentrations of triglyceride-rich lipoproteins and manage hypertriglyceridemia-associated pancreatitis [138146]. Acutely, when oral therapy cannot be used, plasmapheresis is one way to reduce triglyceride level [147]. Comparing plasmapheresis with conservative therapy, it was found that plasmapheresis was not more beneficial than conservative therapy [34, 148, 149]. In uncontrolled chylomicronemia, insulin infusion elicited a greater degree of triglyceride reduction than plasmapheresis [150]. Of note, the risk of hypoglycemia should be addressed during insulin administration. To date, there are no controlled clinical studies that demonstrate the superiority of plasmapheresis on conservative therapy, including dietary restriction, fluid replacement, analgesia, and control of secondary factors. Therefore, at present, some centers only recommend plasmapheresis in severe hypertriglyceridemia associated with pregnancy. It is common practice to perform plasmapheresis when triglyceride level is above $60 \mathrm{mmol} / \mathrm{l}$ to prevent the development of acute pancreatitis and hyperviscosity syndrome. Plasmapheresis is also used at a triglyceride value of $40 \mathrm{mmol} / \mathrm{l}$, in case of abdominal complaints and symptoms of hyperviscosity syndrome. Plasmapheresis reduces triglyceride levels without affecting the underlying cause, therefore treatment for the causes of 
hypertriglyceridemia should also be initiated at the same time.

\section{Novel aspects of this review}

Fredrickson's classification of hyperlipoproteinemias are still taught and used in several regions of Europe; however, based upon the most recent data, such classification seems to be outdated. Therefore, we aimed to harmonize previous nomenclature with recent knowledge in our review in order to mitigate potential misunderstandings and help daily bedside routine.

Despite some other valuable reviews, we tried to reveal the complexity and the difficulties of the diagnosis of hypertriglyceridemia and chylomicronemia from the clinicians' point of view. In the light of these challenges, we also aimed to detail the most up-to-date therapeutic options highlighting their practical significance and usability. Additionally, we tried to draw the attention to the fact that some, experimentally fascinating, treatment approaches failed to live up to the initial expectations and necessitated discontinuation of such drug development.

\section{Conclusions}

Chylomicronemias leading to hypertriglyceridemia represent a major clinical burden with the potential development of life-threatening pancreatitis and cardiovascular diseases. Although a very large proportion of these individuals have a multifactorial form of chylomicronemia and hypertriglyceridemia, that may be exacerbated by common conditions such as obesity, diabetes mellitus, alcohol intake and administration of certain drugs, a minor proportion of CS subjects have a monogenic genetic background with severe and persistent chylomicronemia leading to recurrent pancreatitis, cardiovascular complications and fatty liver disease. These underline the importance of the early diagnosis and proper treatment of this patient population. Novel therapeutic agents may offer solution for the effective treatment of severe hypertriglyceridemias including FCS.

\footnotetext{
Abbreviations

ANGPTL: Angiopoietin-like proteins; apo: Apolipoprotein; CS: Chylomicronemia syndrome; DHA: Doxosahexaenoic acid; DGAT1: Diacylglycerol O-acyltransferase 1; DNA: Deoxyribonucleic acid; EPA: Eicosapentaenoic acid; FCS: Familial chylomicronemia syndrome; FH: Familiar hypercholesterolemia; FPLD: Familial partial lipodystrophy; GPIHBP1: Glycosylphosphatidylinositol-anchored high density lipoproteinbinding protein 1; HDL: High-density lipoprotein; HMGCOA: Hydroxymethylglutaryl-coenzyme A; HSPG: Heparan sulfate proteoglycan; IDL: Intermediate-density lipoprotein; LDL: Low-density lipoprotein; LPL: Lipoprotein lipase; LMF1: Lipase maturation factor-1; MFCS: Multifactorial chylomicronemia syndrome; MTP: Microsomal triglyceride transfer protein; NASH: Nonalcoholic steatohepatitis; PCSK9: Proprotein convertase subtilisin/kexin type 9; PPAR: Peroxisome proliferator activating receptor; SNP: Single nucleotide polymorphisms; SREBP: Sterol regulatory element-binding proteins; VLDL: Very-low density lipoproteins
}

Acknowledgements

Not applicable.

\section{Authors' contributions}

All authors equally contributed to write manuscript. All authors read and approved the final manuscript.

\section{Funding}

The publication was supported by the project GINOP-2.3.2-15-2016-00005. The project was supported by the European Union and co-financed by the European Regional Development Fund. Open Access funding provided by University of Debrecen.

Availability of data and materials

Not applicable.

\section{Declarations}

Ethics approval and consent to participate

Not applicable.

\section{Consent for publication \\ Not applicable.}

\section{Competing interests}

The authors declare that they have no competing interests.

\section{Author details}

'Division of Metabolic Diseases, Department of Internal Medicine, University of Debrecen Faculty of Medicine, Nagyerdei krt. 98, Debrecen H-4032, Hungary. ${ }^{2}$ Department of Hypertension, WAM University Hospital in Lodz, Medical University of Lodz, Lodz, Poland. ${ }^{3}$ Polish Mother's Memorial Hospital Research Institute (PMMHRI), Lodz, Poland.

Received: 25 November 2021 Accepted: 30 January 2022

Published online: 10 February 2022

\section{References}

1. Santos-Baez LS, Ginsberg HN. Hypertriglyceridemia-Causes, Significance, and Approaches to Therapy. Front Endocrinol (Lausanne). 2020;11:616. https:// doi.org/10.3389/fendo.2020.00616.

2. Goldberg RB, Chait A. A Comprehensive Update on the Chylomicronemia Syndrome. Front Endocrinol (Lausanne). 2020;11:593931. https://doi.org/1 0.3389/fendo.2020.593931.

3. Yuan G, Al-Shali KZ, Hegele RA. Hypertriglyceridemia: its etiology, effects and treatment. CMAJ. 2007;176(8):1113-20. https://doi.org/10.1503/cmaj. 060963.

4. Mead JR, Irvine SA, Ramji DP. Lipoprotein lipase: structure, function, regulation, and role in disease. J Mol Med (Berl). 2002;80(12):753-69. https:// doi.org/10.1007/s00109-002-0384-9.

5. Williams KJ. Molecular processes that handle -- and mishandle -- dietary lipids. J Clin Invest. 2008;1 18(10):3247-59. https://doi.org/10.1172/JCI35206.

6. Okubo M, Toromanovic A, Ebara T, Murase T. Apolipoprotein C-II Tuzla: a novel large deletion in APOC2 caused by Alu-Alu homologous recombination in an infant with apolipoprotein C-II deficiency. Clin Chim Acta. 2015;438:148-53. https://doi.org/10.1016/..cca.2014.08.022.

7. Lam CW, Yuen YP, Cheng WF, Chan YW, Tong SF. Missense mutation Leu72Pro located on the carboxyl terminal amphipathic helix of apolipoprotein C-II causes familial chylomicronemia syndrome. Clin Chim Acta. 2006;364(1-2):256-9. https://doi.org/10.1016/j.cca.2005.07.025.

8. Streicher R, Geisel J, Weisshaar C, Avci H, Oette K, Müller-Wieland D, et al. A single nucleotide substitution in the promoter region of the apolipoprotein C-Il gene identified in individuals with chylomicronemia. J Lipid Res. 1996; 37(12):2599-607. https://doi.org/10.1016/50022-2275(20)37463-0.

9. Péterfy M. Lipase maturation factor 1: a lipase chaperone involved in lipid metabolism. Biochim Biophys Acta. 2012;1821(5):790-4. https://doi.org/10.1 016/j.bbalip.2011.10.006.

10. Young SG, Davies BS, Voss CV, Gin P, Weinstein MM, Tontonoz P, et al. GPIHBP1, an endothelial cell transporter for lipoprotein lipase. J Lipid Res. 2011;52(11):1869-84. https://doi.org/10.1194/jr.R018689. 
11. Calandra S, Priore Oliva C, Tarugi P, Bertolini S. APOA5 and triglyceride metabolism, lesson from human APOA5 deficiency. Curr Opin Lipidol. 2006: 17(2):122-7. https://doi.org/10.1097/01.mol.0000217892.00618.54.

12. Nilsson SK, Heeren J, Olivecrona G, Merkel M. Apolipoprotein A-V; a potent triglyceride reducer. Atherosclerosis. 2011;219(1):15-21. https://doi.org/10.1 016/j.atherosclerosis.2011.07.019.

13. Huff MW, Hegele RA. Apolipoprotein C-III: going back to the future for a lipid drug target. Circ Res. 2013;112(11):1405-8. https://doi.org/10.1161/ CIRCRESAHA.113.301464

14. Kersten S. Angiopoietin-like 3 in lipoprotein metabolism. Nat Rev Endocrinol. 2017;13(12):731-9. https://doi.org/10.1038/nrendo.2017.119.

15. Ono M, Shimizugawa T, Shimamura M, Yoshida K, Noji-Sakikawa C, Ando Y, et al. Protein region important for regulation of lipid metabolism in angiopoietin-like 3 (ANGPTL3): ANGPTL3 is cleaved and activated in vivo. $J$ Biol Chem. 2003;278(43):41804-9. https://doi.org/10.1074/jbc.M302861200.

16. Shimizugawa T, Ono M, Shimamura M, Yoshida K, Ando Y, Koishi R, et al. ANGPTL3 decreases very low density lipoprotein triglyceride clearance by inhibition of lipoprotein lipase. J Biol Chem. 2002;277(37):33742-8. https:// doi.org/10.1074/jbc.M203215200.

17. Lee EC, Desai U, Gololobov G, Hong S, Feng X, Yu XC, et al. Identification of a new functional domain in angiopoietin-like 3 (ANGPTL3) and angiopoietin-like 4 (ANGPTL4) involved in binding and inhibition of lipoprotein lipase (LPL). J Biol Chem. 2009;284(20):13735-45. https://doi. org/10.1074/jbc.M807899200

18. Shan L, Yu XC, Liu Z, Hu Y, Sturgis LT, Miranda ML, et al. The angiopoietinlike proteins ANGPTL3 and ANGPTL4 inhibit lipoprotein lipase activity through distinct mechanisms. J Biol Chem. 2009;284(3):1419-24. https://doi. org/10.1074/jbc.M808477200.

19. Sonnenburg WK, Yu D, Lee EC, Xiong W, Gololobov G, Key B, et al. GPIHBP1 stabilizes lipoprotein lipase and prevents its inhibition by angiopoietin-like 3 and angiopoietin-like 4. J Lipid Res. 2009;50(12):2421-9. https://doi.org/10.11 94/jlr.M900145-JLR200.

20. Yau MH, Wang Y, Lam KS, Zhang J, Wu D, Xu A. A highly conserved motif within the $\mathrm{NH} 2$-terminal coiled-coil domain of angiopoietin-like protein 4 confers its inhibitory effects on lipoprotein lipase by disrupting the enzyme dimerization. J Biol Chem. 2009;284(18):11942-52. https://doi.org/10.1074/ jbc.M809802200.

21. Quagliarini F, Wang Y, Kozlitina J, Grishin NV, Hyde R, Boerwinkle E, et al. Atypical angiopoietin-like protein that regulates ANGPTL3. Proc Natl Acad Sci U S A. 2012;109(48):19751-6. https://doi.org/10.1073/pnas.1217552109.

22. Chi X, Britt EC, Shows HW, Hjelmaas AJ, Shetty SK, Cushing EM, et al. ANGP TL8 promotes the ability of ANGPTL3 to bind and inhibit lipoprotein lipase. Mol Metab. 2017;6(10):1137-49. https://doi.org/10.1016/j.molmet.2017.06. 014.

23. Mattijssen F, Kersten S. Regulation of triglyceride metabolism by angiopoietin-like proteins. Biochim Biophys Acta. 2012;1821(5):782-9. https://doi.org/10.1016/j.bbalip.2011.10.010.

24. Wolska A, Dunbar RL, Freeman LA, Ueda M, Amar MJ, Sviridov DO, et al. Apolipoprotein C-II: new findings related to genetics, biochemistry, and role in triglyceride metabolism. Atherosclerosis. 2017;267:49-60. https://doi.org/1 0.1016/j.atherosclerosis.2017.10.025.

25. Chokshi N, Blumenschein SD, Ahmad Z, Garg A. Genotype-phenotype relationships in patients with type I hyperlipoproteinemia. J Clin Lipidol. 2014;8(3):287-95. https://doi.org/10.1016/j.jacl.2014.02.006

26. Hegele RA, Pollex RL. Hypertriglyceridemia: phenomics and genomics. Mol Cell Biochem. 2009;326(1-2):35-43. https://doi.org/10.1007/s11010-0080005-1.

27. Hegele RA. Plasma lipoproteins: genetic influences and clinical implications. Nat Rev Genet. 2009;10(2):109-21. https://doi.org/10.1038/nrg2481.

28. Johansen CT, Kathiresan S, Hegele RA. Genetic determinants of plasma triglycerides. J Lipid Res. 2011;52(2):189-206. https://doi.org/10.1194/jlr. R009720.

29. Gotoda T, Shirai K, Ohta T, Kobayashi J, Yokoyama S, Oikawa S, et al. Diagnosis and management of type I and type $\mathrm{V}$ hyperlipoproteinemia. J Atheroscler Thromb. 2012;19(1):1-12. https://doi.org/10.5551/jat.10702.

30. Leaf DA. Chylomicronemia and the chylomicronemia syndrome: a practical approach to management. Am J Med. 2008;121(1):10-2. https://doi.org/10.1 016/j.amjmed.2007.10.004.

31. Rouis M, Dugi KA, Previato L, Patterson AP, Brunzell JD, Brewer HB, et al. Therapeutic response to medium-chain triglycerides and omega-3 fatty acids in a patient with the familial chylomicronemia syndrome. Arterioscler
Thromb Vasc Biol. 1997;17(7):1400-6. https://doi.org/10.1161/01.atv.17.7.14 00.

32. Parker F, Bagdade JD, Odland GF, Bierman EL. Evidence for the chylomicron origin of lipids accumulating in diabetic eruptive xanthomas: a correlative lipid biochemical, histochemical, and electron microscopic study. J Clin Invest. 1970;49(12):2172-87. https://doi.org/10.1172/JCl106436.

33. Whitcomb DC. Clinical practice. Acute pancreatitis N Engl J Med. 2006; 354(20):2142-50. https://doi.org/10.1056/NEJMcp054958.

34. Valdivielso P, Ramírez-Bueno A, Ewald N. Current knowledge of hypertriglyceridemic pancreatitis. Eur J Intern Med. 2014;25(8):689-94. https://doi.org/10.1016/j.ejim.2014.08.008.

35. Ranson $\mathrm{JH}$. Etiological and prognostic factors in human acute pancreatitis: a review. Am J Gastroenterol. 1982;77(9):633-8.

36. Balthazar EJ, Robinson DL, Megibow AJ, Ranson JH. Acute pancreatitis: value of CT in establishing prognosis. Radiology. 1990;174(2):331-6. https://doi. org/10.1148/radiology.174.2.2296641.

37. Fortson MR, Freedman SN, Webster PD. Clinical assessment of hyperlipidemic pancreatitis. Am J Gastroenterol. 1995;90(12):2134-9.

38. Sandhu S, Al-Sarraf A, Taraboanta C, Frohlich J, Francis GA. Incidence of pancreatitis, secondary causes, and treatment of patients referred to a specialty lipid clinic with severe hypertriglyceridemia: a retrospective cohort study. Lipids Health Dis. 2011;10(1):157. https://doi.org/10.1186/1476-511X-1 $0-157$.

39. Christian JB, Arondekar B, Buysman EK, Johnson SL, Seeger JD, Jacobson TA. Clinical and economic benefits observed when follow-up triglyceride levels are less than $500 \mathrm{mg} / \mathrm{dL}$ in patients with severe hypertriglyceridemia. J Clin Lipidol. 2012;6(5):450-61. https://doi.org/10.1016/j.jacl.2012.08.007.

40. Feoli-Fonseca JC, Lévy E, Godard M, Lambert M. Familial lipoprotein lipase deficiency in infancy: clinical, biochemical, and molecular study. J Pediatr. 1998;133(3):417-23. https://doi.org/10.1016/s0022-3476(98)70280-x.

41. Khokhar AS, Seidner DL. The pathophysiology of pancreatitis. Nutr Clin Pract. 2004;19(1):5-15. https://doi.org/10.1177/011542650401900105.

42. Brahm A, Hegele RA. Hypertriglyceridemia. Hypertriglyceridemia Nutrients. 2013;5(3):981-1001. https://doi.org/10.3390/nu5030981.

43. Hegele RA, Ginsberg HN, Chapman MJ, Nordestgaard BG, Kuivenhoven JA, Averna $\mathrm{M}$, et al. The polygenic nature of hypertriglyceridaemia: implications for definition, diagnosis, and management. Lancet Diabetes Endocrinol. 2014:2(8):655-66. https://doi.org/10.1016/S2213-8587(13)70191-8.

44. Rahalkar AR, Hegele RA. Monogenic pediatric dyslipidemias: classification, genetics and clinical spectrum. Mol Genet Metab. 2008;93(3):282-94. https:// doi.org/10.1016/j.ymgme.2007.10.007.

45. Sugandhan S, Khandpur S, Sharma VK. Familial chylomicronemia syndrome. Pediatr Dermatol. 2007;24(3):323-5. https://doi.org/10.1111/j.1525-1470.2007. 00415.x.

46. Brunzell JD, Bierman EL. Chylomicronemia syndrome. Interaction of genetic and acquired hypertriglyceridemia. Med Clin North Am. 1982;66(2):455-68. https://doi.org/10.1016/s0025-7125(16)31430-4

47. Brahm AJ, Hegele RA. Chylomicronaemia--current diagnosis and future therapies. Nat Rev Endocrinol. 2015;11(6):352-62. https://doi.org/10.1038/ nrendo.2015.26.

48. Martín-Campos JM, Julve J, Roig R, Martínez S, Errico TL, Martínez-Couselo S, et al. Molecular analysis of chylomicronemia in a clinical laboratory setting: diagnosis of 13 cases of lipoprotein lipase deficiency. Clin Chim Acta. 2014; 429:61-8. https://doi.org/10.1016/j.cca.2013.11.025

49. Stefanutti C, Gozzer M, Pisciotta L, D'Eufemia P, Bosco G, Morozzi C, et al. A three month-old infant with severe hyperchylomicronemia: molecular diagnosis and extracorporeal treatment. Atheroscler Suppl. 2013;14(1):73-6. https://doi.org/10.1016/j.atherosclerosissup.2012.10.020.

50. Voss CV, Davies BS, Tat S, Gin P, Fong LG, Pelletier C, et al. Mutations in lipoprotein lipase that block binding to the endothelial cell transporter GPIHBP1. Proc Natl Acad Sci U S A. 2011;108(19):7980-4. https://doi.org/10.1 073/pnas.1100992108.

51. Pasalić D, Jurcić Z, Stipancić G, Ferencak G, Leren TP, Djurovic S, et al. Missense mutation W86R in exon 3 of the lipoprotein lipase gene in a boy with chylomicronemia. Clin Chim Acta. 2004;343(1-2):179-84. https://doi. org/10.1016/j.cccn.2004.01.029.

52. Jap TS, Jenq SF, Wu YC, Chiu CY, Cheng HM. Mutations in the lipoprotein lipase gene as a cause of hypertriglyceridemia and pancreatitis in Taiwan. Pancreas. 2003;27(2):122-6. https://doi.org/10.1097/00006676-200308000-00003.

53. Henderson HE, Bijvoet SM, Mannens MA, Bruin T, Erkelens DW, Hayden MR, et al. lle225Thr loop mutation in the lipoprotein lipase (LPL) gene is a de 
novo event. Am J Med Genet. 1998;78(4):313-6. https://doi.org/10.1002/ (sici)1096-8628(19980724)78:4<313:.:aid-ajmg1>3.0.co;2-m.

54. Foubert L, De Gennes JL, Benlian P, Truffert J, Miao L, Hayden MR. Compound heterozygosity for frameshift mutations in the gene for lipoprotein lipase in a patient with early-onset chylomicronemia. Hum Mutat. 1998:Suppl 1:S141-4. https://doi.org/10.1002/humu.1380110148.

55. Ma Y, Wilson BI, Bijvoet S, Henderson HE, Cramb E, Roederer G, et al. A missense mutation (Asp250----Asn) in exon 6 of the human lipoprotein lipase gene causes chylomicronemia in patients of different ancestries. Genomics. 1992;13(3):649-53. https://doi.org/10.1016/0888-7543(92)90136-g.

56. Hegele RA, Ban MR, Hsueh N, Kennedy BA, Cao H, Zou GY, et al. A polygenic basis for four classical Fredrickson hyperlipoproteinemia phenotypes that are characterized by hypertriglyceridemia. Hum Mol Genet. 2009;18(21):4189-94. https://doi.org/10.1093/hmg/ddp361.

57. Dron JS, Hegele RA. Genetics of Hypertriglyceridemia. Front Endocrinol (Lausanne). 2020;11:455. https://doi.org/10.3389/fendo.2020.00455.

58. Albers K, Schlein C, Wenner K, Lohse P, Bartelt A, Heeren J, et al. Homozygosity for a partial deletion of apoprotein A-V signal peptide results in intracellular missorting of the protein and chylomicronemia in a breastfed infant. Atherosclerosis. 2014;233(1):97-103. https://doi.org/10.1016/j.a therosclerosis.2013.12.009.

59. Ariza MJ, Rioja J, Ibarretxe D, Camacho A, Díaz-Díaz JL, Mangas A, et al. Molecular basis of the familial chylomicronemia syndrome in patients from the National Dyslipidemia Registry of the Spanish Atherosclerosis Society. J Clin Lipidol. 2018;12(6):1482-92.e3. https://doi.org/10.1016/j.jacl.2018.07.013.

60. Pirillo A, Norata GD, Catapano AL. Postprandial lipemia as a cardiometabolic risk factor. Curr Med Res Opin. 2014;30(8):1489-503. https://doi.org/10.1185/ 03007995.2014.909394

61. Belhassen M, Van Ganse E, Nolin M, Bérard M, Bada H, Bruckert E, et al. 10year comparative follow-up of familial versus multifactorial Chylomicronemia syndromes. J Clin Endocrinol Metab. 2021;106(3):e1332e42. https://doi.org/10.1210/clinem/dgaa838.

62. Lewis GF, Xiao C, Hegele RA. Hypertriglyceridemia in the genomic era: a new paradigm. Endocr Rev. 2015;36(1):131-47. https://doi.org/10.1210/er.2 014-1062.

63. Chait A, Eckel RH. The Chylomicronemia syndrome is Most often multifactorial: a narrative review of causes and treatment. Ann Intern Med. 2019;170(9):626-34. https://doi.org/10.7326/M19-0203.

64. Bagias C, Xiarchou A, Bargiota A, Tigas S. Familial partial lipodystrophy (FPLD): recent insights. Diabetes Metab Syndr Obes. 2020;13:1531-44. https://doi.org/10.2147/DMSO.S206053.

65. Lotta LA, Gulati P, Day FR, Payne F, Ongen H, van de Bunt $M$, et al. Integrative genomic analysis implicates limited peripheral adipose storage capacity in the pathogenesis of human insulin resistance. Nat Genet. 2017; 49(1):17-26. https://doi.org/10.1038/ng.3714

66. Muller DP, Pavlou C, Whitelaw AG, McLintock D. The effect of pregnancy and two different contraceptive pills on serum lipids and lipoproteins in a woman with a type III hyperlipoproteinaemia pattern. Br J Obstet Gynaecol. 1978;85(2):127-33. https://doi.org/10.1111/j.1471-0528.1978.tb10466.x.

67. Beigneux AP, Miyashita K, Ploug M, Blom DJ, Ai M, Linton MF, et al. Autoantibodies against GPIHBP1 as a cause of hypertriglyceridemia. N Engl J Med. 2017;376(17):1647-58. https://doi.org/10.1056/NEJMoa1611930.

68. Murphy MJ, Sheng X, MacDonald TM, Wei L. Hypertriglyceridemia and acute pancreatitis. JAMA Intern Med. 2013;173(2):162-4. https://doi.org/10.1001/2 013.jamainternmed.477.

69. Pedersen SB, Langsted A, Nordestgaard BG. Nonfasting mild-to-moderate hypertriglyceridemia and risk of acute pancreatitis. JAMA Intern Med. 2016; 176(12):1834-42. https://doi.org/10.1001/jamainternmed.2016.6875.

70. Stefanutti C, Labbadia G, Morozzi C. Severe hypertriglyceridemia-related acute pancreatitis. Ther Apher Dial. 2013;17(2):130-7. https://doi.org/1 0.1111/1744-9987.12008.

71. Davidson M, Stevenson M, Hsieh A, Ahmad Z, Crowson C, Witztum JL. The burden of familial chylomicronemia syndrome: interim results from the INFOCUS study. Expert Rev Cardiovasc Ther. 2017;15(5):415-23. https://doi. org/10.1080/14779072.2017.1311786.

72. Gelrud A, Williams KR, Hsieh A, Gwosdow AR, Gilstrap A, Brown A. The burden of familial chylomicronemia syndrome from the patients' perspective. Expert Rev Cardiovasc Ther. 2017;15(11):879-87. https://doi. org/10.1080/14779072.2017.1372193.

73. Marmontel O, Di Filippo M, Marcais C, Nony S, Dumoux M, Serveaux-Dancer $M$, et al. Alterations in plasma triglycerides lipolysis in patients with history of multifactorial chylomicronemia. Atherosclerosis. 2017;265:22-8. https:// doi.org/10.1016/j.atherosclerosis.2017.07.030.

74. Moulin P, Dufour R, Averna M, Arca M, Cefalù AB, Noto D, et al. Identification and diagnosis of patients with familial chylomicronaemia syndrome (FCS): expert panel recommendations and proposal of an "FCS score". Atherosclerosis. 2018;275:265-72. https://doi.org/10.1016/j.a therosclerosis.2018.06.814.

75. Jialal I, Amess W, Kaur M. Management of hypertriglyceridemia in the diabetic patient. Curr Diab Rep. 2010;10(4):316-20. https://doi.org/10.1007/ s11892-010-0124-4.

76. Leaf DA, Connor WE, Illingworth DR, Bacon SP, Sexton G. the hypolipidemic effects of gemfibrozil in type $V$ hyperlipidemia. A double-blind, crossover study. JAMA. 1989;262(22):3154-60. https://doi.org/10.1001/jama.1989.0343 0220077034.

77. Gotto AM, Moon JE. Pharmacotherapies for lipid modification: beyond the statins. Nat Rev Cardiol. 2013;10(10):560-70. https://doi.org/10.1038/nrca rdio.2013.117.

78. Staels B, Dallongeville J, Auwerx J, Schoonjans K, Leitersdorf E, Fruchart JC. Mechanism of action of fibrates on lipid and lipoprotein metabolism. Circulation. 1998;98(19):2088-93. https://doi.org/10.1161/01. cir.98.19.2088.

79. Sahebkar A, Chew GT, Watts GF. Recent advances in pharmacotherapy for hypertriglyceridemia. Prog Lipid Res. 2014;56:47-66. https://doi.org/10.1016/ j.plipres.2014.07.002.

80. litake C, Masuda D, Koseki M, Yamashita S. Marked effects of novel selective peroxisome proliferator-activated receptor a modulator, pemafibrate in severe hypertriglyceridemia: preliminary report. Cardiovasc Diabetol. 2020; 19(1):201. https://doi.org/10.1186/s12933-020-01172-8.

81. Minamizuka T, Kobayashi J, Tada H, Miyashita K, Koshizaka M, Maezawa Y, et al. Detailed analysis of lipolytic enzymes in a Japanese woman of familial lipoprotein lipase deficiency - effects of pemafibrate treatment. Clin Chim Acta. 2020;510:216-9. https://doi.org/10.1016/j.cca.2020.07.031.

82. CARLSON LA. Studies on the effect of nicotinic acid on catecholamine stimulated lipolysis in adipose tissue in vitro. Acta Med Scand. 1963;173: 719-22. https://doi.org/10.1111/j.0954-6820.1963.tb17457.x.

83. Kamanna VS, Kashyap ML. Mechanism of action of niacin. Am J Cardiol. 2008;101 (8A):20B-6B. https://doi.org/10.1016/j.amjcard.2008.02.029.

84. Goldberg A, Alagona P, Capuzzi DM, Guyton J, Morgan JM, Rodgers J, et al. Multiple-dose efficacy and safety of an extended-release form of niacin in the management of hyperlipidemia. Am J Cardiol. 2000;85(9):1100-5. https://doi.org/10.1016/s0002-9149(00)00703-7.

85. Gille A, Bodor ET, Ahmed K, Offermanns S. Nicotinic acid: pharmacological effects and mechanisms of action. Annu Rev Pharmacol Toxicol. 2008;48(1): 79-106. https://doi.org/10.1146/annurev.pharmtox.48.113006.094746.

86. Park Y, Harris WS. Omega-3 fatty acid supplementation accelerates chylomicron triglyceride clearance. J Lipid Res. 2003;44(3):455-63. https:// doi.org/10.1194/Jr.M200282-JLR200.

87. Davidson $\mathrm{MH}$. Mechanisms for the hypotriglyceridemic effect of marine omega-3 fatty acids. Am J Cardiol. 2006;98(4A):27i-33i. https://doi.org/10.101 6/j.amjcard.2005.12.024.

88. Skulas-Ray AC, West SG, Davidson MH, Kris-Etherton PM. Omega-3 fatty acid concentrates in the treatment of moderate hypertriglyceridemia. Expert Opin Pharmacother. 2008;9(7):1237-48. https://doi.org/10.1517/14656566.9. 7.1237 .

89. Connor WE, DeFrancesco CA, Connor SL. N-3 fatty acids from fish oil. Effects on plasma lipoproteins and hypertriglyceridemic patients. Ann N Y Acad Sci. 1993;683(1 Dietary Lipid):16-34. https://doi.org/10.1111/j.1749-6632.1993.tb3 5689.x.

90. Berglund L, Brunzell JD, Goldberg AC, Goldberg IJ, Stalenhoef A. Treatment options for hypertriglyceridemia: from risk reduction to pancreatitis. Best Pract Res Clin Endocrinol Metab. 2014;28(3):423-37. https://doi.org/10.1016/j. beem.2013.10.002.

91. Slivkoff-Clark KM, James AP, Mamo JC. The chronic effects of fish oil with exercise on postprandial lipaemia and chylomicron homeostasis in insulin resistant viscerally obese men. Nutr Metab (Lond). 2012;9:9. https://doi.org/1 0.1186/1743-7075-9-9

92. Brinton EA, Ballantyne CM, Guyton JR, Philip S, Doyle RT, Juliano RA, et al. Lipid effects of Icosapent ethyl in women with diabetes mellitus and persistent high triglycerides on statin treatment: ANCHOR trial subanalysis. J Women's Health (Larchmt). 2018;27(9):1170-6. https://doi.org/10.1089/jwh.2 017.6757. 
93. Bhatt DL, Steg PG, Miller M, Brinton EA, Jacobson TA, Ketchum SB, et al. Cardiovascular risk reduction with Icosapent ethyl for hypertriglyceridemia. N Engl J Med. 2019;380(1):11-22. https://doi.org/10.1056/NEJMoa1812792.

94. Wierzbicki AS, Hardman TC, Viljoen A. New lipid-lowering drugs: an update. Int J Clin Pract. 2012;66(3):270-80. https://doi.org/10.1111/j.1742-1241.2011. 02867.x.

95. Naik R, Obiang-Obounou BW, Kim M, Choi Y, Lee HS, Lee K. Therapeutic strategies for metabolic diseases: small-molecule diacylglycerol acyltransferase (DGAT) inhibitors. ChemMedChem. 2014;9(11):2410-24 https://doi.org/10.1002/cmdc.201402069.

96. DeVita RJ, Pinto S. Current status of the research and development of diacylglycerol O-acyltransferase 1 (DGAT1) inhibitors. J Med Chem. 2013; 56(24):9820-5. https://doi.org/10.1021/jm4007033.

97. Denison H, Nilsson C, Kujacic M, Löfgren L, Karlsson C, Knutsson M, et al. Proof of mechanism for the DGAT1 inhibitor AZD7687: results from a firsttime-in-human single-dose study. Diabetes Obes Metab. 2013;15(2):136-43. https://doi.org/10.1111/dom.12002.

98. Denison H, Nilsson C, Löfgren L, Himmelmann A, Mårtensson G, Knutsson M, et al. Diacylglycerol acyltransferase 1 inhibition with AZD7687 alters lipid handling and hormone secretion in the gut with intolerable side effects: a randomized clinical trial. Diabetes Obes Metab. 2014;16(4):334-43. https:// doi.org/10.1111/dom.12221.

99. Khetarpal SA, Zeng X, Millar JS, Vitali C, Somasundara AVH, Zanoni P, et al. A human APOC3 missense variant and monoclonal antibody accelerate apoCIII clearance and lower triglyceride-rich lipoprotein levels. Nat Med. 2017; 23(9):1086-94. https://doi.org/10.1038/nm.4390.

100. Fujimoto K, Koishi R, Shimizugawa T, Ando Y. Angptl3-null mice show low plasma lipid concentrations by enhanced lipoprotein lipase activity. Exp Anim. 2006;55(1):27-34. https://doi.org/10.1538/expanim.55.27.

101. Maki KC, Bays HE, Dicklin MR. Treatment options for the management of hypertriglyceridemia: strategies based on the best-available evidence. J Clin Lipidol. 2012;6(5):413-26. https://doi.org/10.1016/j.jacl.2012.04.003.

102. Graham MJ, Lee RG, Bell TA, Fu W, Mullick AE, Alexander VJ, et al. Antisense oligonucleotide inhibition of apolipoprotein C-III reduces plasma triglycerides in rodents, nonhuman primates, and humans. Circ Res. 2013; 112(11):1479-90. https://doi.org/10.1161/CIRCRESAHA.111.300367.

103. Meyers CD, Tremblay K, Amer A, Chen J, Jiang L, Gaudet D. Effect of the DGAT1 inhibitor pradigastat on triglyceride and apoB48 levels in patients with familial chylomicronemia syndrome. Lipids Health Dis. 2015;14(1):8. https://doi.org/10.1186/s12944-015-0006-5.

104. Pecin I, Nedic, M., Reiner, Z. Volanesorsen. Antisense oligonucleotide targeting ApoC-III, treatment of familial chylomicronemia syndrome, treatment of hypertriglyceridemia, treatment of lipodystrophy. Drugs Fut. 2016:417-421.

105. Witztum JL, Gaudet D, Freedman SD, Alexander VJ, Digenio A, Williams KR et al. Volanesorsen and triglyceride levels in familial Chylomicronemia syndrome. N Engl J Med. 2019:381(6):531-42. https://doi.org/10.1056/ NEJMoa1715944.

106. Ioanna Gouni-Berthold VA, Andres Digenio, Robert DuFour ES-T, Steve Martin, Patrick Moriarty, Steve Hughes JW, Daniel Gaudet, Eric Stroes. Apolipoprotein C-III inhibition with volanesorsen in patients with hypertriglyceridemia (COMPASS): a randomized, double-blind, placebocontrolled trial. J Clin Lipidol. 2017:794-5.

107. Paik J, Duggan S. Volanesorsen: First Global Approval. Drugs. 2019;79(12): 1349-54. https://doi.org/10.1007/s40265-019-01168-z.

108. Gaudet D, Méthot J, Kastelein J. Gene therapy for lipoprotein lipase deficiency. Curr Opin Lipidol. 2012;23(4):310-20. https://doi.org/10.1097/ MOL.0b013e3283555a7e.

109. Carpentier AC, Frisch F, Labbé SM, Gagnon R, de Wal J, Greentree S, et al. Effect of alipogene tiparvovec (AAV1-LPL(S447X)) on postprandial chylomicron metabolism in lipoprotein lipase-deficient patients. J Clin Endocrinol Metab. 2012;97(5):1635-44. https://doi.org/1 0.1210/jc.2011-3002

110. Gaudet D, Méthot J, Déry S, Brisson D, Essiembre C, Tremblay G, et al. Efficacy and long-term safety of alipogene tiparvovec (AAV1-LPLS447X) gene therapy for lipoprotein lipase deficiency: an open-label trial. Gene Ther. 2013;20(4):361-9. https://doi.org/10.1038/gt.2012.43.

111. Rip J, van Dijk KW, Sierts JA, Kastelein JJ, Twisk J, Kuivenhoven JA. AAV1$\mathrm{LPL}(\mathrm{S} 447 \mathrm{X})$ gene therapy reduces hypertriglyceridemia in apoE2 knock in mice. Biochim Biophys Acta. 2006;1761(10):1163-8. https://doi.org/10.1016/j. bbalip.2006.08.008.
112. Haller JF, Mintah IJ, Shihanian LM, Stevis P, Buckler D, Alexa-Braun CA, et al. ANGPTL8 requires ANGPTL3 to inhibit lipoprotein lipase and plasma triglyceride clearance. J Lipid Res. 2017;58(6):1166-73. https://doi.org/10.11 94/jlr.M075689.

113. Kaplan R, Zhang T, Hernandez M, Gan FX, Wright SD, Waters MG, et al. Regulation of the angiopoietin-like protein 3 gene by LXR. J Lipid Res. 2003; 44(1):136-43. https://doi.org/10.1194/jlr.m200367-jlr200.

114. Ge H, Cha JY, Gopal H, Harp C, Yu X, Repa JJ, et al. Differential regulation and properties of angiopoietin-like proteins 3 and 4. J Lipid Res. 2005;46(7): 1484-90. https://doi.org/10.1194/jlr.M500005-JLR200.

115. Inaba T, Matsuda M, Shimamura M, Takei N, Terasaka N, Ando Y, et al. Angiopoietin-like protein 3 mediates hypertriglyceridemia induced by the liver X receptor. J Biol Chem. 2003;278(24):21344-51. https://doi.org/10.1 074/jbc.M213202200

116. Fugier C, Tousaint JJ, Prieur X, Plateroti M, Samarut J, Delerive P. The lipoprotein lipase inhibitor ANGPTL3 is negatively regulated by thyroid hormone. J Biol Chem. 2006;281(17):11553-9. https://doi.org/10.1074/jbc. M512554200.

117. Inukai K, Nakashima Y, Watanabe M, Kurihara S, Awata T, Katagiri $H_{\text {, et al }}$ ANGPTL3 is increased in both insulin-deficient and -resistant diabetic states. Biochem Biophys Res Commun. 2004;317(4):1075-9. https://doi.org/10.1016/ j.bbrc.2004.03.151.

118. Lu B, Moser A, Shigenaga JK, Grunfeld C, Feingold KR. The acute phase response stimulates the expression of angiopoietin like protein 4. Biochem Biophys Res Commun. 2010;391(4):1737-41. https://doi.org/10.1016/j.bbrc.2 009.12.145.

119. Matsusue K, Miyoshi A, Yamano S, Gonzalez FJ. Ligand-activated PPARbeta efficiently represses the induction of LXR-dependent promoter activity through competition with RXR. Mol Cell Endocrinol. 2006;256(1-2):23-33. https://doi.org/10.1016/j.mce.2006.05.005.

120. Shimamura M, Matsuda M, Kobayashi S, Ando Y, Ono M, Koishi R, et al. Angiopoietin-like protein 3, a hepatic secretory factor, activates lipolysis in adipocytes. Biochem Biophys Res Commun. 2003;301(2):604-9. https://doi. org/10.1016/s0006-291x(02)03058-9.

121. Pramfalk C, Parini P, Gustafsson U, Sahlin S, Eriksson M. Effects of high-dose statin on the human hepatic expression of genes involved in carbohydrate and triglyceride metabolism. J Intern Med. 2011;269(3):333-9. https://doi. org/10.1111/j.1365-2796.2010.02305.x.

122. Koishi R, Ando Y, Ono M, Shimamura M, Yasumo H, Fujiwara T, et al. Angptl3 regulates lipid metabolism in mice. Nat Genet. 2002;30(2):151-7. https://doi.org/10.1038/ng814.

123. Sehgal A, Vaishnaw A, Fitzgerald K. Liver as a target for oligonucleotide therapeutics. J Hepatol. 2013;59(6):1354-9. https://doi.org/10.1016/j.jhep.2 013.05.045.

124. Gusarova V, Alexa CA, Wang Y, Rafique A, Kim JH, Buckler D, et al. ANGPTL3 blockade with a human monoclonal antibody reduces plasma lipids in dyslipidemic mice and monkeys. J Lipid Res. 2015;56(7):1308-17. https://doi. org/10.1194/jlr.M054890.

125. Wang Y, Gusarova V, Banfi S, Gromada J, Cohen JC, Hobbs HH. Inactivation of ANGPTL3 reduces hepatic VLDL-triglyceride secretion. J Lipid Res. 2015; 56(7):1296-307. https://doi.org/10.1194/jlr.M054882.

126. Ando $Y$, Shimizugawa T, Takeshita S, Ono M, Shimamura M, Koishi R, et al. A decreased expression of angiopoietin-like 3 is protective against atherosclerosis in apoE-deficient mice. J Lipid Res. 2003;44(6):1216-23. https://doi.org/10.1194/jlr.M300031-JLR200.

127. Gaudet D, Karwatowska-Prokopczuk E, Baum SJ, Hurh E, Kingsbury J, Bartlett VJ, et al. Vupanorsen, an N-acetyl galactosamine-conjugated antisense drug to ANGPTL3 mRNA, lowers triglycerides and atherogenic lipoproteins in patients with diabetes, hepatic steatosis, and hypertriglyceridaemia. Eur Heart J. 2020;41(40):3936-45. https://doi.org/1 0.1093/eurheartj/ehaa689.

128. Chan DC, Watts GF, Barrett PH, Martins IJ, James AP, Mamo JC, et al. Effect of atorvastatin on chylomicron remnant metabolism in visceral obesity: a study employing a new stable isotope breath test. J Lipid Res. 2002;43(5): 706-12. https://doi.org/10.1016/S0022-2275(20)30112-7.

129. Marbach JA, McKeon JL, Ross JL, Duffy D. Novel treatments for familial hypercholesterolemia: pharmacogenetics at work. Pharmacotherapy. 2014; 34(9):961-72. https://doi.org/10.1002/phar.1441.

130. Sacks FM, Stanesa M, Hegele RA. Severe hypertriglyceridemia with pancreatitis: thirteen years' treatment with lomitapide. JAMA Intern Med. 2014;174(3):443-7. https://doi.org/10.1001/jamainternmed.2013.13309. 
131. Cuchel M, Meagher EA, du Toit TH, Blom DJ, Marais AD, Hegele RA, et al. Efficacy and safety of a microsomal triglyceride transfer protein inhibitor in patients with homozygous familial hypercholesterolaemia: a single-arm, open-label, phase 3 study. Lancet. 2013;381(9860):40-6. https://doi.org/10.1 016/50140-6736(12)61731-0.

132. Vuorio A, Tikkanen MJ, Kovanen PT. Inhibition of hepatic microsomal triglyceride transfer protein - a novel therapeutic option for treatment of homozygous familial hypercholesterolemia. Vasc Health Risk Manag. 2014; 10:263-70. https://doi.org/10.2147/NHRM.S36641.

133. Rader DJ, Kastelein JJ. Lomitapide and mipomersen: two first-in-class drugs for reducing low-density lipoprotein cholesterol in patients with homozygous familial hypercholesterolemia. Circulation. 2014;129(9):1022-32. https://doi.org/10.1161/CIRCULATIONAHA.113.001292.

134. deGoma EM. Lomitapide for the management of homozygous familial hypercholesterolemia. Rev Cardiovasc Med. 2014;15(2):109-18

135. Zimmer M, Bista P, Benson EL, Lee DY, Liu F, Picarella D, et al. CAT-2003: a novel sterol regulatory element-binding protein inhibitor that reduces steatohepatitis, plasma lipids, and atherosclerosis in apolipoprotein E*3-Leiden mice. Hepatol Commun. 2017;1 (4):311-25. https://doi.org/10.1002/hep4.1042.

136. Michael Zimmer DP, Feng Liu, Pradeep Bista, Diana Lee, Chi Vu, and Michael Jirousek. CAT-2003 is a Novel Small Molecule That Inhibits Proprotein Convertase Subtilisin/Kexin Type 9 Production and Lowers Non--HighDensity Lipoprotein Cholesterol. Arterioscler Thromb Vasc Biol. 2014:A6.

137. ClinicalTrials.gov Identifier: NCT02098278. https://clinicaltrials.gov/ct2/show/ NCT02098278?term=CAT-2003.

138. Hen K, Bogdański P, Pupek-Musialik D. Successful treatment of severe hypertriglyceridemia with plasmapheresis--case report. Pol Merkur Lekarski. 2009;26(151):62-4.

139. Basar R, Uzum AK, Canbaz B, Dogansen SC, Kalayoglu-Besisik S, Altay-Dadin $\mathrm{S}$, et al. Therapeutic apheresis for severe hypertriglyceridemia in pregnancy. Arch Gynecol Obstet. 2013;287(5):839-43. https://doi.org/10.1007/s00404013-2786-z.

140. Lennertz A, Parhofer KG, Samtleben W, Bosch T. Therapeutic plasma exchange in patients with chylomicronemia syndrome complicated by acute pancreatitis. Ther Apher. 1999;3(3):227-33. https://doi.org/10.1046/j.1 526-0968.1999.00158.x.

141. Seda G, Meyer JM, Amundson DE, Daheshia M. Plasmapheresis in the management of severe hypertriglyceridemia. Crit Care Nurse. 2013;33(4):1823; quiz 4. https://doi.org/10.4037/ccn2013346.

142. Izquierdo-Ortiz MJ, Abaigar-Luquin P. Severe hypertriglyceridaemia. Treatment with plasmapheresis. Nefrologia. 2012;32(3):417-8. https://doi. org/10.3265/Nefrologia.pre2012.Feb.11394.

143. Syed H, Bilusic M, Rhondla C, Tavaria A. Plasmapheresis in the treatment of hypertriglyceridemia-induced pancreatitis: a community hospital's experience. J Clin Apher. 2010;25(4):229-34. https://doi.org/10.1002/jca.20232.

144. Ewald N, Kloer HU. Severe hypertriglyceridemia: an indication for apheresis? Atheroscler Suppl. 2009;10(5):49-52. https://doi.org/10.1016/S15675688(09)71810-0.

145. Iskandar SB, Olive KE. Plasmapheresis as an adjuvant therapy for hypertriglyceridemia-induced pancreatitis. Am J Med Sci. 2004;328(5):290-4. https://doi.org/10.1097/00000441-200411000-00010.

146. Zsíros N, Kovács B, Paragh G, Balla J, Harangi M. Successful plasmapheresis treatment of severe hypertriglyceridemia during late pregnancy. Vessel Plus. 2019;2019.

147. Domínguez-Muñoz JE, Jünemann F, Malfertheiner P. Hyperlipidemia in acute pancreatitis. Cause or epiphenomenon? Int J Pancreatol. 1995;18(2): 101-6. https://doi.org/10.1007/BF02785883.

148. Chen JH, Yeh JH, Lai HW, Liao CS. Therapeutic plasma exchange in patients with hyperlipidemic pancreatitis. World J Gastroenterol. 2004;10(15):2272-4. https://doi.org/10.3748/wjg.v10.115.2272.

149. Piolot A, Nadler F, Cavallero E, Coquard JL, Jacotot B. Prevention of recurrent acute pancreatitis in patients with severe hypertriglyceridemia: value of regular plasmapheresis. Pancreas. 1996;13(1):96-9. https://doi.org/1 0.1097/00006676-199607000-00013

150. Thuzar M, Shenoy W, Malabu UH, Schrale R, Sangla KS. Extreme hypertriglyceridemia managed with insulin. J Clin Lipidol. 2014;8(6):630-4. https://doi.org/10.1016/j.jacl.2014.09.004.

\section{Publisher's Note}

Springer Nature remains neutral with regard to jurisdictional claims in published maps and institutional affiliations.

\section{Ready to submit your research? Choose BMC and benefit from:}

- fast, convenient online submission

- thorough peer review by experienced researchers in your field

- rapid publication on acceptance

- support for research data, including large and complex data types

- gold Open Access which fosters wider collaboration and increased citations

- maximum visibility for your research: over $100 \mathrm{M}$ website views per year

At $\mathrm{BMC}$, research is always in progress.

Learn more biomedcentral.com/submissions 